\title{
The parathyroid hormone-2 receptor: current status
}

\author{
Ted B. Usdin ${ }^{1}$ \\ 1 Section on Genetics, National Institute of Mental Health, \\ Bethesda, Maryland 20892, U. S. A. \\ Accepted 18 March 1997 \\ Abbreviations: PTH2, parathyroid hormone-2; PTHrP, parathyroid hormone-related \\ peptide
}

\begin{abstract}
G-protein coupled receptors form a large superfamily of plasma membrane proteins which serve a variety of signal transduction roles. New receptors continue to be identified. Based on sequence homology the superfamily can currently be divided into three families, the rhodopsin family which includes the vast majority of identified receptors, and the secretin and metabotropic glutamate receptor families which share a general architecture with each other and the rhodopsin family but no obvious sequence identity. Screening for additional members of the secretin family led to the identification of the parathyroid hormone-2 (PTH2) receptor. Ligand recognition by the $\mathrm{PTH} 2$ receptor partially overlaps that of the PTH/parathyroid hormone-related peptide (PTHrP) receptor. This has facilitated structure-function analysis of ligands for these receptors. The physiological role of the $\mathrm{PTH} 2$ receptor is under investigation but its distribution suggests that it may be a neurotransmitter receptor and could participate in modulation of a number of organ systems. The relative abundance of $\mathrm{PTH} 2$ receptor $\mathrm{mRNA}$ in the brain and the inability to detect mRNA encoding PTH, its only currently identified ligand, suggest the existence of another endogenous ligand, for which evidence has recently been obtained.
\end{abstract}

Keywords: parathyroid hormone, receptors, G-protein, neurotransmitters, brain

\section{Introduction}

G-protein coupled receptors are important mediators of intercellular communication throughout the body. They are activated by a large number of neurotransmitters, hormones, and cytokines as well as paracrine, and autocrine factors. Mutations in G-protein coupled receptors, either resulting in loss of function or constitutive function, have been identified as the cause of a number of diseases ( for recent review see (Raymond, 1994, Pearce et al., 1995, Spiegel, 1996). Blockade or activation of G-protein coupled receptors is the mechanism of action of many therapeutic drugs. Thus, identification of new G-protein coupled receptors provides tools for the study of physiological systems as well as new potential therapeutic targets.

\section{Cloning of the PTH2 receptor}

Following identification of the secretin, calcitonin, and PTH/PTHrP receptors by functional expression (Ishihara et al., 1991; Jüpner et al., 1991; Lin et al., 1991) it became apparent that these receptors were members of a distinct protein family. On alignment members share $20-60 \%$ of their amino acid sequence. Their overall topology is predicted to be similar to that of the majority of other G-protein coupled receptors (the rhodopsin family), including seven hydrophobic membrane spanning domains, an extracellular amino terminus and an intracellular carboxyl end. However, there is no obvious primary sequence homology between this recently identified group of receptors, referred to as the secretin family, and the receptors within the rhodopsin family. Additional members of the secretin receptor family have been identified using the initial members as probes, by further expression screening, and by PCR using degenerate primers based on conserved domains within the initially identified receptors (Ishihara et al., 1992; Mayo, 1992; Thorens, 1992; Gaylinn et al., 1993; Hashimoto et al., 1993; Jelinek et al., 1993; Marrow et al., 1993; Perrin et al., 1993; Pisegna et al., 1993; Sexton et al., 1993; Sreedharan et al., 1993; Usdin et al., 1993, 1995; Inagaki et al., 1994). The PTH2 receptor was identified by the degenerate primer PCR approach, and the full cDNA sequence obtained by a combination of hybridization, using the initial PCR fragment as a probe, and the RACE technique (Usdin et al., 1995).

\section{Ligand specificity of the PTH2 receptor}

The amino acid sequence of the $\mathrm{PTH} 2$ receptor is approximately $50 \%$ identical to that of th PTH/PTHrP receptor (Figure 1) and is somewhat less similar to other members of the secretin receptor family. That lead us suppose that the ligand for the PTH2 receptor would be similar to the ligand(s) for the PTH/PTHrP receptor. $\mathrm{PTH}$ potently activates the $\mathrm{PTH} 2$ receptor, causing the accumulation of CAMP in cells expressing it, and thus 


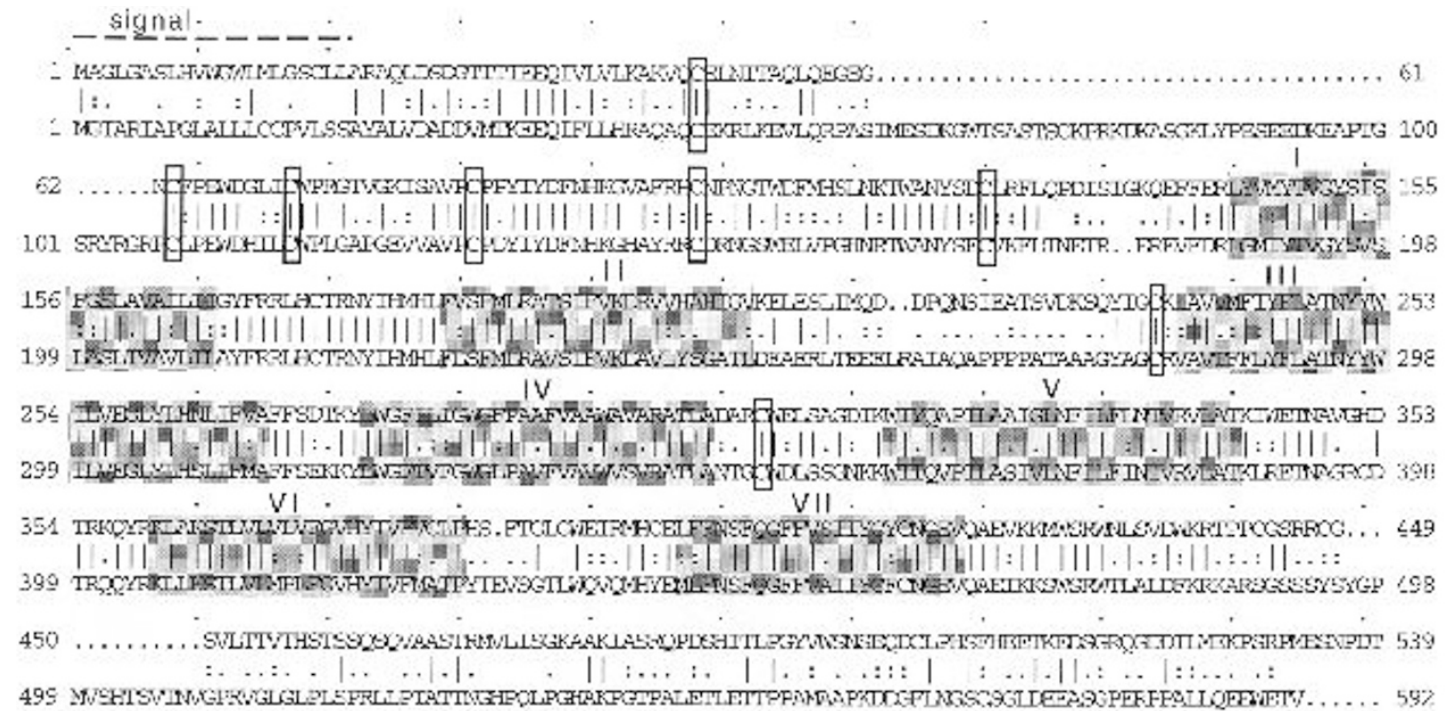

Figure 1. Receptor sequence alignment. The deduced amino acid sequences of the human PTH2 receptor (upper sequence) and the human PTH/PTHrP receptor (lower sequence) are shown. A putative signal sequence is indicated at the $\mathrm{N}$ terminal. Predicted transmembrane domains are shaded, identical residues are indicated by vertical bars and similar residues by dots, according to the Gap algorithm of the GCG package (GCG, 1994). Conserved cysteine residues within the extracellular domains are enclosed by boxes.

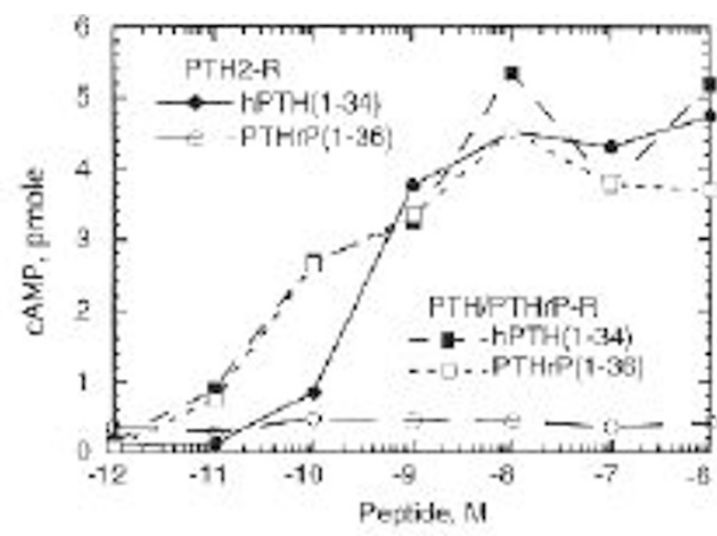

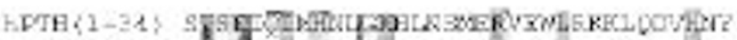
PrषTP(1-36) A

Figure 2. Receptor specificity. HEK293 cell lines stably expressing the PTH2 or PTH/PTHrP receptor were incubated for $10 \mathrm{~min}$ with the indicated peptides and then total cAMP accumulation determined by RIA (Usdin, 1997). The sequences of PTH and PTHrP are indicated with identical residues shaded and the two residues demonstrated to be critical for PTH2 receptor interaction in bold. leading to its name. The striking pharmacological difference between the PTH2 receptor and the PTH/ PTHrP receptor is that while the PTH/PTHrP receptor is activated virtually identically by PTH and a second peptide, parathyroid hormone-related peptide (PTHrP) (Abou-Samra et al., 1992; Schipani et al., 1993), the PTH2 receptor is activated only by PTH (Usdin et al., 1995). PTH activates the PTH2 receptor with very similar potency to its effect at the PTH/PTHrP receptor while PTHrP has almost no ability to activate the PTH2 receptor (Figure 2). PTHrP is also much less potent than PTH in displacing radiolabeled PTH from the PTH2 receptor in competitive binding assays (Behar et al., 1996; Gardella et al., 1996).

PTH and PTHrP probably bind to the same or overlapping sites on the PTH/PTHrP receptor (Gardella et al., 1996). The first 34 residues of PTH and 36 residues of PTHrP are generally used to study ligand interaction with the PTH/PTHrP receptor since they are sufficient for full activation of the PTH/PTHrP receptor and bind with high affinity. PTH and PTHrP share 8 or 9 amino acid residues of their first 13 (depending on the species) and only 3 in the remaining sequence (Figure 2). The general conclusions from study of the interaction of a number of analogs of PTH and PTHrP with the PTH/ $\mathrm{PTHrP}$ receptor is that non-identical residues in the two peptides may make similar contacts with the receptor, and that the carboxyl terminal part of the peptide seems to contribute significantly to receptor binding while the amino terminus is required for receptor activation (for review and references see Potts et al., 1995). PTHrP at micromolar concentration slightly antagonizes PTH activation of the PTH2 receptor. This is probably too high a concentration to have any physiological role. However, the synthetic analog PTHrP (7-34) displaces 
radiolabeled $\mathrm{PTH}$ from the $\mathrm{PTH} 2$ receptor more potently than does PTHrP (1-34) (Behar et al., 1996a, b). Detailed examination of the interaction of PTH and PTHrP analogs with the $\mathrm{PTH} 2$ receptor, including hybrid peptides composed of the amino end of one and the carboxyl end of the other peptide, have extended the functional comparison of these peptides, and support the suggestion that the C-terminal part is the "address" and the Nterminal the "message" (Gardella et al., 1996). Substitution of phenylalanine 23 in PTHrP with tryptophan, which is at the equivalent position in $\mathrm{PTH}$, increases its affinity for the PTH2 receptor 70 fold, turning it into a potent antagonist. Substitution of histidine at residue 5 of PTHrP with isoleucine from the equivalent position in $\mathrm{PTH}$ allows it to activate the $\mathrm{PTH} 2$ receptor while maintaining a very low affinity. Combining the two substitutions turns PTHrP into a potent, high affinity PTH2 receptor agonist (Gardella et al., 1996). The reciprocal substitutions decrease the affinity and potency of PTH at the PTH2 receptor. Further structural studies, exchanging residues between the $\mathrm{PTH} / \mathrm{PTHrP}$ receptor and the $\mathrm{PTH} 2$ receptor, aimed at identifying residues within the receptors which are responsible for discriminating between PTH and PTHrP are underway.

\section{Distribution of the PTH2 receptor}

The physiological role of the PTH/PTHrP receptor is well characterized as the mediator of PTH action in the kidney, where it promotes calcium reabsorption, inhibits phosphate reabsorption and stimulates synthesis of 1 , 25-dihydroxy-Vitamin $D$, and in bone where it causes bone resorption and releases of calcium (Potts et al., 1995). PTH synthesis in the parathyroid gland is under negative feedback by serum calcium and thus PTH and the PTH/PTHrP receptor serve a major physiological role in mineral homeostasis. The PTH/PTHrP receptor also mediates the effects of PTHrP. These functions are currently being elucidated. PTHrP was originally referred to as humoral hypercalcemia of malignancy factor, an activity produced by some lung, breast, skin and other tumors which cause hypercalcemia (for review see Martin et al., 1995). The purified protein causes effects virtually identical to those of PTH in most assays, and at the cloned PTH/PTHrP receptor. Molecular cloning of PTHrP revealed that it is a distinct gene product with significant homology to PTH at the amino terminal of the protein. PTHrP has an essential role in normal development as demonstrated by the lethality of disruption of its gene in transgenic mice (Karaplis et al., 1994). One of the recently identified roles of the PTH/PTHrP receptor as a receptor for $\mathrm{PTHrP}$ is in mediation the effects of locally produced PTHrP on chondrocyte differentiation (Vorkamp et al., 1996).

The physiological functions of the $\mathrm{PTH} 2$ receptor remain to be determined. One initial approach for investigation of the biological role of the $\mathrm{PTH} 2$ receptor is to study its distribution. Northern blots demonstrate that it's mRNA is much more abundant in the brain than in other tissues (Usdin et al., 1995). PTH2 receptor mRNA is also detectable by Northern blot in the pancreas, placenta, testis and lung, but it cannot be detected in the kidney. PTH2 receptor mRNA can barely be detected in the kidney and some bone-derived cells using reversetranscription followed by PCR (RT-PCR). While these experiments were not performed quantitatively, it is clear that the PTH2 receptor mRNA expression in these tissues is at least several thousand fold less than the levels of $\mathrm{PTH} / \mathrm{PTH} \mathrm{P}$ receptor mRNA thus while the $\mathrm{PTH} 2$ receptor is extremely selective for $\mathrm{PTH}$, based on its distribution, it does not appear to be responsible for

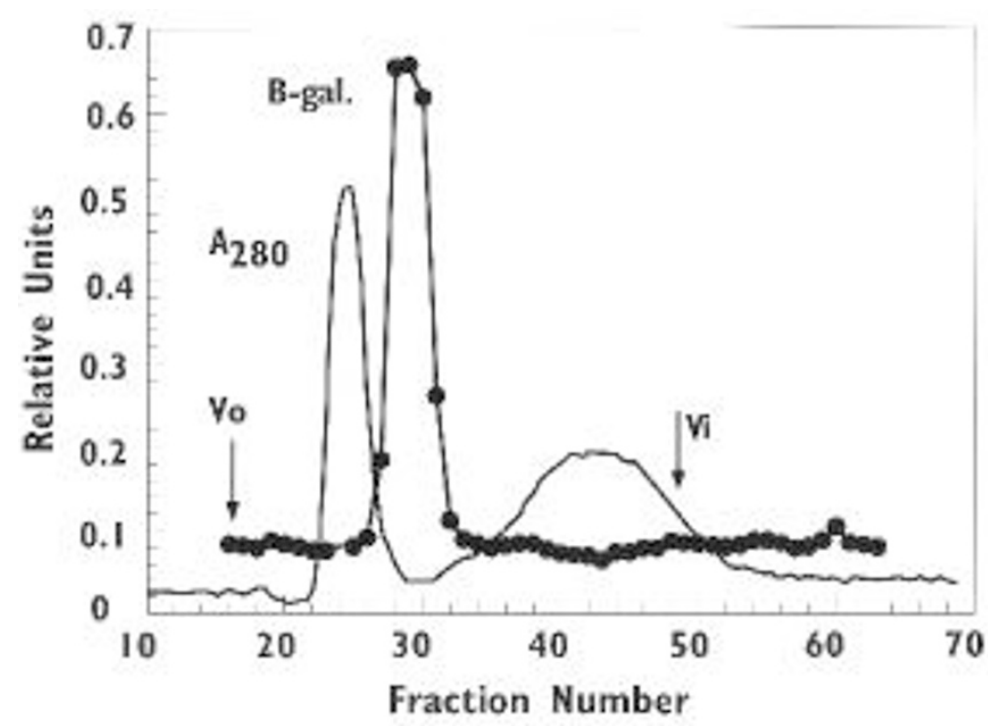

Figure 3. Gel filtration chromatography demonstrating a potential PTH2 receptor selective ligand. An acid-acetone extract prepared from bovine hypothalamus was chromatographed on a Sephadex G50 column in $50 \%$ acetic acid (Usdin, 1997). 
the well characterized effects of PTH.

In situ hybridization histochemistry demonstrates a more widespread distribution of $\mathrm{PTH} 2$ receptor $\mathrm{mRNA}$ than is apparent from Northern blots (Usdin et al., 1996). Some of the areas where it is present include vascular and cardiac endothelium and smooth muscle, as well as the exocrine pancreas, bronchi and other pulmonary cells, mucus producing cells within the gastrointestinal tract, and sperm within the head of the epididymis. An extremely small number of cells within the kidney do express PTH2 receptor mRNA and they appear to be at the vascular pole of glomeruli, consistent with expression within the juxtaglomerular apparatus. The presence of $\mathrm{PTH} 2$ receptor mRNA in each of these areas suggests that it may be involved in modulation the specific functions of these tissues, but it is also possible that it is involved in more general metabolic responses. Within the central nervous system $\mathrm{PTH} 2$ receptor mRNA is synthesized by neurons within a number of distinct nuclei. As a broad generalization these seem to be part of hippocampal input and output circuits, but without further identification of these cells and their connectivity it is difficult to speculate on the role of the $\mathrm{PTH} 2$ receptor in the brain, beyond the suggestion that it may function as a neuro-transmitter receptor.

\section{Evidence for a PTH2 receptor-selective ligand}

While PTH2 receptor mRNA is relatively abundant in the brain it has been difficult to detect mRNA encoding PTH, its only known ligand. We hypothesized that there might be another ligand within the brain which acts at the PTH2 receptor. When fractions from gel filtration chromatography of an acid-acetone extract of bovine hypothalamus were assayed for stimultaion of CAMP accumulation in $\mathrm{PTH} 2$ receptor expressing cells a single peak of activity was detected (Figure 3) (Usdin, 1997). Several criteria support the suggestion that this is a new $\mathrm{PTH} 2$ receptor-selective ligand. The partially purified material does not have any significant effect on the cell lines from which $\mathrm{PTH} 2$ receptor expressing cells were generated, demonstrating that it acts at the $\mathrm{PTH} 2$ receptor and not at an endogenous receptor. The material has a much larger effect on $\mathrm{PTH} 2$ receptor expressing cells than on PTH/PTHrP receptor expressing cells, while both synthetic amino terminal PTH fragments and PTH extracted from bovine parathyroid gland have a somewhat greater effect on the PTH/PTHrP receptor. In addition an antiserum raised against bovine PTH almost completely blocks $\mathrm{PTH} 2$ receptor activation by $\mathrm{PTH}$ but has very little effect on the partially purified hypothalamic extract. This PTH2 receptor selective activity is recovered following acid extraction and reverse-phase HPLC chromatography suggesting that it is a peptide which can be purified, and subsequently sequenced, by conventional biochemical techniques.

\section{Conclusions}

The PTH2 receptor was identified as part of a screen for novel G-protein coupled receptors expressed in the brain. Its distribution suggests that it may play a role in exocrine pancreatic secretion, blood pressure control, and sperm maturation, and that it functions as a neurotransmitter receptor. Drugs acting at the PTH/PTHrP receptor are currently being evaluated for treatment of osteoporosis, and these drugs may have side effects at the PTH2 receptor which need to be considered. The structural similarity of the $\mathrm{PTH} 2$ receptor to the PTH/PTHrP receptor and the existence of peptide ligands activating both receptors, as well as ligands selectively activating the $\mathrm{PTH} / \mathrm{PTHrP}$ receptor, has allowed for refinement of the structure-function analysis of those peptides, and will facilitate analysis of the receptor structures providing selectivity. The identification of the $\mathrm{PTH} 2$ receptor has provided the impetus and functional basis for the search for a new bioactive peptide which may be a new hormone or neurotransmitter.

\section{References}

Abou-Samra A. B., Jüpner, H., Force, T., Freeman, M. W., Kong, X. F., Schipani, E., Urena, P., Richards, J., Bonventre, J. V., Potts, J. T., Kronenbery, H. M. and Segre, G. V. (1992) Expression cloning of a common receptor for parathyroid hormone and parathyroid hormone-related peptide from rat osteoblast-like cells: A single receptor stimulates intracellular accumulation of both CAMP and inositol triphosphates and increases intracellular free calcium. Cell Biol. 89: 2732-2736

Behar V., Nakamoto, C., Greenberg, Z., Bisello, A., Suva, L. J., Rosenblatt, M. and Chorev, M. (1996a) Histidine at position 5 is the specificity "switch" between two parathyroid hormone receptor subtypes. Endocrinology 137: 4217-4224

Behar V., Pines, M., Nakamoto, C., Greenberg, Z., Bisellin, A., Stueckle, S. M., Bessalle, R., Usdin, T. B., Chorev, M., Rosenblatt, M. and Suva, L. J. (1996b) The human PTH2 receptor: binding and signal transduction properties of the stably expressed recombinant receptor. Endocrinology 137: 2748-2757

Gardella T. J., Luck, M. D., Jensen, G. S., Usdin, T. B. and Jüppner, H. (1996) Converting parathyroid hormone-related peptide (PTHrP) into a potent $\mathrm{PTH}-2$ receptor agonist. J. Biol. Chem. 271: 19888-19893

Gaylinn B. D., Harrison, J. K., Zysk, J. R., Lyons, C. E., Lynch, K. R., Thorner, M. O. (1993) Molecular-cloning and expression of a human anteriorpituitary receptor for growth hormone-releasing hormone. Mol. Endocrinol. 7: 77-84

GCG (1994) Program Manual for the Wisconsin Package. Madison, Wisconsin, Genetics Computer Group

Hashimoto H., Ishihara, T., Shigemoto, R., Mori, K. and Nagata, S. (1993) Molecular cloning and tissue distribution of a receptor for pituitary adenylate cyclase-activating polypeptide. Neuron 11: 333-342

Inagaki N., Yoshida, H., Mizuta, M., Mizuno, N., Fujii, Y., Gonoi, T., Miyazaki, J. and Seino, S. (1994) Cloning and functional-characterization of a 3rd pituitary adenylate cyclase-activating polypeptide receptor subtype expressed in insulin-secreting cells. Proc. Natl. Acad. Sci. USA 91: 2679-2683 
Ishihara T., Nakamura, S., Kaziro, Y., Takahashi, T., Takahashi, K. and Nagata, S. (1991) Molecular cloning and expression of a cDNA encoding the secretin receptor. EMBO J. 10: 1635-1641

Ishihara T., Shigemoto, R., More, K., Takahashi, K. and Nagata, S. (1992) Functional expression and tissue distribution of a novel receptor for vasoactive intestinal polypeptide. Neuron 8: 811-819

Jelinek L. J., Lok, S., Rosenberg, G. B., Smith, R. A., Grant, F. J., Biggs, S., Bensch, B. A., Kuijper, J. L., Sheppard, P. O., Sprecher, C. A., Jüpner H., Abou-Samra, A. B., Freeman, M., Kong, X. F., Schipani, E., Richards, J., Kolakowski, L. F., Hock, J., Potts, J. T., Kronenberg, H. M. and Segre, G. V. (1991) A G protein-linked receptor for parathyroid hormone and parathyroid hormone-related peptide. Science 254: $1024-$ 1024

Karaplis A. C., Luz, A., Glowacki, J., Bronson, R. T., Tybulewicz, V. L. J., Kronenberg, H. M. and Mulligan, R. C. (1994) Lethal skeletal dysplasia from targeted disruption of the parathyroid hormone-related peptide gene. Genes Develop. 8: 277-289

Lin H. Y., Harris, T. L., Flannery, M. S., Aruffo, A., Kaji, E. H., Gorn, A., Kolakowski, L. F., Lodish, H. F. and Goldring, S. R. (1991) Expression cloning of an adenylate cyclasecoupled calcitonin receptor. Science 254: 1022-1024

Martin T. J. and Moseley, J. M. (1995) parathyroid hormone-related protein. In Williamsi textbook of endocrinology, pp. 967-977, Saunders, Philadelphia

Mayo K. E. (1992) Molecular-cloning and expression of a pituitary-specific receptor for growth hormone-releasing hormone. Mol. Endocrinol. 6: 1734-1744

Morrow J. A., Lutz, E. M., West, K. M., Fink, G. and Harmar, A. J. (1993) Molecularcloning and expression of a cDNA-encoding a receptor for pituitary adenylate-cyclase activating polypeptide (PACAP). FEBS Lett. 329: 99-105

O'hara, P. J., Foster, D., Walker, K. M., Chen, L. H. J., McKernan, P. A. and Kindsvogel, W. (1993) Expression cloning and signaling properties of the rat glucagon receptor. Science 259: 1614-1616

Pearce, S. H. and Trump, D. (1995) G-protein-coupled receptors in endocrine disease. QJM 88: 3-8

Perrin, M. H., Donaldson, C. J., Chen, R., Lewis, K. A.. and Vale, W. W. (1993) Cloning and functional expression of a rat brain corticotropin releasing factor (CRF) receptor. Endocrinology 133: 3058-3061

Pisegnal, J. and Wank, S. (1993) Molecular cloning and functional expression of the pituitary adenylate cyclase-activating polypeptide type I receptor. Proc. Natl. Acad. Sci. USA 90: 6345-6349

Potts, J. T. J., Bringhurst, F. R., Gardella, T., Nussbaum, S., Segre, G. and Kronenberg, H. (1995) Parathyroid hormone: physiology, chemistry, biosynthesis, secretion, metabolism and mode of action. In Williamsi textbook of endocrinology. pp. 920-966, Saunders, Philadelphia

Raymond, J. R. (1994) Hereditary and acquired defects in signaling through the hormone-receptor-G protein complex. Am. J. Physiol. 266: F163-74

Sexton P. M., Houssami, S., Hilton, J. M., Keeffe, O., Center, R. J., Gillespie, M. T., Darcy, P. and Findlay, D. M.(1993) Identification of Brain Isoforms of the Rat Calcitonin

\section{Receptor Mol Endocrinol 7: 815-821}

Schipani E., Karga, H., Karaplis, A. C., Potts, J. T., Kronenberg, H. M., Segre, G. V., Abou-Samra, A. B. and Jüpner, H. (1993) Identical complementary deoxyribonucleic acids encode a hyman renal and bone parathyroid hormone (PTH)/PTH-related peptide receptor. Endocrinology 132: 2157-2165

Spiegel A. M. (1996) Mutations in G proteins and G protein-coupled receptors in endocrine disease. J. Clin. Endocrinol. Metab. 81: 2434-2442

Sreedharan S. P., Patel, D. R., Huang, J. X. and Goetzl, E. J.(1993) Cloning and functional expression of a human neuroendocrine vasoactive intestinal peptide receptor. Biochem. Biophys. Res. Commun. 193: 546-553

Thorens B. (1992) Expression cloning of the pancreatic beta-cell receptor for the glucoincretin hormone glucagon-like peptide 1. Proc. Natl. Acad. Sci. USA 89: 8641-8645

Usdin T. B., Mezey, E., Button, D. C., Brownstein, M. J. and Bonner, T. I. (1993) Gastric inhibitory polypeptide receptor, a member of the secretin-vasoactive intestinal peptide receptor family, is widely distributed in peripheral organs and the brain. Endocrinology 133: $2861-2870$

Usdin T. B., Gruber, C. and Bonner, T. I. (1995) Identification and functional expression of a receptor selectively recognizing parathyroid hormone, the PTH2 receptor. J. Biol. Chem. 270: 15455-15458

Usdin T. B., Bonner, T. I., Harta, G. and Mezey, É. (1996) Distribution of PTH2 receptor mRNA in rat. Endocrinology 137: 4285-4297

Usdin T. B. (1997) Evidence for a parathyroid hormone-2 receptor selective ligand in the hypothalamus. Endocrinology 138: 831-838

Vortkamp A., Lee. K., Lanske, B., Segre, G. V., Kronenberg, H. M. and Tabin, C. J. (1996) Regulation of rate of cartilage differentiation by Indian hedgehog and PTHrelated protein. Science 273: 613-622 